This is an Accepted Manuscript of an article published by Taylor \& Francis in The Asia Pacific Journal of Anthropology on 8 July 2014, available online:

http://www.tandfonline.com/doi/abs/10.1080/14442213.2014.916341? journalCode=rtap 20

\title{
Legal Mobilisation and Justice: Insights from the Constitutional Court Case on International Standard Schools in Indonesia
}

\author{
Andrew Rosser and Jayne Curnow \\ University of Adelaide
}

\begin{abstract}
Analysis of the role of courts in shaping access to justice in Indonesia has emphasised the role of judges and the incentives created for them by courts' institutional design. Alternatively, it has focused on individual justice-seekers and their capacities to choose between alternative pathways through the legal repertoire. In this paper, we suggest that 'support structures for legal mobilisation' (SSLMs) have also played an important role in shaping access to justice by influencing both the potential for legal mobilisation and the type of justice sought. In making this argument, we focus on a recent Constitutional Court case on 'international standard schools'. In this case, a group of parents were able to mobilize for legal action only because NGOs provided the required technical expertise and financial resources while the central involvement of an anti-corruption NGO in the SSLM shifted the focus from parents concerns about discrimination to corruption.
\end{abstract}

Keywords: Access to Justice, Indonesia, legal mobilisation, international standard schools

\section{Acknowledgements}

We wish to thanks the Australian Research Council for funding the research on which this paper is based through grant number FT110100078 and Laurens Bakker, Jaap Timmer and two anonymous reviewers for their helpful comments on an earlier draft of this paper. 
This is an Accepted Manuscript of an article published by Taylor \& Francis in The Asia Pacific Journal of Anthropology on 8 July 2014, available online:

http://www.tandfonline.com/doi/abs/10.1080/14442213.2014.916341?journalCode=rtap 20

\section{Introduction}

Much academic analysis of the role of Indonesian courts in shaping access to justice has emphasised the role of judicial activism and the incentives for judges created by courts' institutional design. In general, it is argued, Indonesian courts are characterized by high levels of corruption and political interference, with the result that rights-friendly judgments have only occurred when heroic judges have resisted financial temptation and political pressure and/or the design of courts has provided incentives for such resistance (Butt 2006; Mietzner 2010). However, the extent of judicial activism and the nature of incentives stemming from courts' design have not been the sole determinants of Indonesian citizens' access to justice through the court system.

Rights provided for in the 1945 Constitution and national laws have only been successfully defended and enforced through courts when citizens have placed a case on the relevant court's docket and presented arguments and evidence to support their case in the first place. Yet such 'legal mobilization' is not inevitable or easy: rights are not 'selfactivating' but realised only through deliberate action on the part of justice-seekers to bring matters to court (Epp 1998). To fully understand the conditions under which Indonesian citizens have been able access justice through the court system, it is thus important to first understand when they mobilize for legal action.

Scholars at Leiden's Van Vollenhoven Institute (VVI) who work with a socio-legal approach have suggested that legal mobilization is essentially a matter of individual choice and the personal characteristics of justice-seekers. Placing the individual justiceseeker at the centre of the analysis, they have focused on the capacities of justice-seekers to choose, strategically or otherwise, between alternative legal pathways (Bedner and Vel 2010) and the way these capacities are shaped by 'problems related to the justice seeker him/herself' such as a 'lack of experience in dealing with formal justice institutions', 'limited legal awareness and knowledge of the law and their rights', 'lack of financial capacity,' and 'negative perceptions of legal institutions and litigation and social stigma incurred from turning to the law to seek justice' (van de Meene and van Rooij 2008, 10- 
This is an Accepted Manuscript of an article published by Taylor \& Francis in The Asia Pacific Journal of Anthropology on 8 July 2014, available online:

http://www.tandfonline.com/doi/abs/10.1080/14442213.2014.916341?journalCode=rtap 20

11). Some scholars in this camp have pointed to the constraints imposed by broader structures of power (Berenschot et al. 2011). But otherwise, they have tended to see 'the demand for justice' as emanating from the choices and acumen of individual justice seekers.

In this paper, we suggest that what Charles Epp (1998) has called 'support structures for legal mobilisation' (SSLMs) also play an important role in shaping the potential for legal mobilization in Indonesia. According to Epp (1998), ordinary citizens are unlikely to mobilize for legal action in relation to rights issues unless they have access to a SSLM comprising (i) organized group support in the form of 'repeat players' - that is, organizations that have extensive experience in using the court system; (ii) financing for legal action from either public or private sources; and (iii) lawyers willing and able to support their case. While Epp developed this idea through an analysis of the US, Britain, India and Canada (Epp 1996; 1998) and had a focus on state-provided legal aid as the key component of the support structure, we argue that his ideas apply to the Indonesian context where private 'cause lawyers' and non-government organizations (NGOs) have played a much more important role in the legal aid sector (Lev 1987; 1998).

Specifically, we argue that while analysis of access to justice in Indonesia needs to remain mindful of the agency of individual justice-seekers, the role of activist judges and court design, it also needs to factor in the way in which SSLMs shape justice-seekers' ability to translate their demands for justice and rights protection into action or, to put it differently, to give these demands some power and force. ${ }^{i}$ At the same time, we also consider the tension between ideal and practical justice stemming from potential contradictions between the political agendas and bases of legal aid NGOs and those of the justice-seekers they are supporting. In focusing on these points, we respond to Cowan's (2006) and Merry's (2006) call for scholars to (i) focus, not on 'asking if human rights are a good idea' but rather 'what difference they make' (Merry 2006, 39) and (ii) consider the role actors in 'the middle'-that is, the space between 'specific situations of suffering and violation' and 'the arena of international law and legal institutions' (Merry 2006, 39). 
This is an Accepted Manuscript of an article published by Taylor \& Francis in The Asia Pacific Journal of Anthropology on 8 July 2014, available online:

http://www.tandfonline.com/doi/abs/10.1080/14442213.2014.916341?journalCode=rtap 20

To support our argument, we examine as a case study recent struggles in Indonesia over the establishment of so-called 'international standard' schools (SBIs or Sekolah Bertaraf Internasional). Heavily subsidized by government and permitted to charge fees, these schools were criticised for breaching Constitutional provisions for free basic education, promoting mismanagement and corruption within the state school system, and worsening inequality and unequal access to opportunity. In 2012, three parents launched and sustained a Constitutional Court case that challenged the constitutionality of SBIs, motivated by a sense of injustice emanating from difficulties they had had in paying for their children to attend these schools. In January 2013, the Constitutional Court found in their favour, effectively bringing an end to the government's SBI policy. ${ }^{\mathrm{ii}}$

We argue that they were able to mobilize for legal action in this case, not simply because they made a strategic decision that taking this matter to court might secure a remedy, but also because local NGOs provided them with access to repeat players and financing, mostly in the form of pro bono contributions from lawyers, witnesses and experts. Without this support structure, we suggest, it is unlikely that the three parents would have been able to successfully launch a Constitutional Court case, let alone sustain it over several months. At the same time, this case points to a key downside of support structures that involve provision of legal assistance by NGOs with particular political agendas: namely, the potential for rights causes to be subordinated to and undermined by these agendas, bringing along adjustments to the kind of justice sought by justice seekers.

In presenting this argument, we begin by briefly outlining the nature of and rationale for the central government's policy on SBIs. We then identify the people who have supported and opposed this policy (or the way it has been implemented), the grounds on which they have done so, and the efforts of people opposed to the policy and its implementation to seek redress for their concerns. We then examine the Constitutional Court case on SBIs that was launched in early 2012, focusing in particular on the way in which NGOs assisted the three parents in mobilizing for legal action. We conclude the paper with a discussion 
This is an Accepted Manuscript of an article published by Taylor \& Francis in The Asia Pacific Journal of Anthropology on 8 July 2014, available online:

http://www.tandfonline.com/doi/abs/10.1080/14442213.2014.916341?journalCode=rtap 20

of the theoretical and policy-related implications of our analysis. In particular, we encourage consideration of ways in which SSLM in Indonesia, as currently constituted, can be strengthened to ensure favourable outcomes for the poor and disadvantaged.

\section{SBI Policy and Rationale}

Under the New Order, Indonesia's school system was characterised by dramatic improvements in access but low quality education. The collapse of the New Order and transition to a more democratic political system in the late 1990s led to a new emphasis on improving the country's international competitiveness by producing 'smart and competitive Indonesians' (Ministry of National Education 2005), an agenda that implied improvements in a whole range of quality-related education indicators: national exam results, the number of qualified teachers, the international and regional rankings of university programs, and the number of medals won in Olympiads. The introduction of SBIs in 2007 was one of the central government's main initiatives for achieving these objectives.

SBIs were distinct from 'international schools' in that they primarily serviced domestic rather than expatriate students. ${ }^{\text {iii }}$ They were defined in government regulations as public and private national schools that 'have already fulfilled all national education standards and which are enriched with certain quality superiorities that originate from OECD member countries or other developed countries'. ${ }^{\text {iv }}$ Specifically, they were required to follow curricula used in OECD or other developed countries, use information and communication technology (ICT) and English in the delivery of these curricula, employ teaching staff who are fluent in English and a minimum proportion of whom have postgraduate qualifications, provide international standard facilities (particularly with regards to ICT), and create sister school programs with either leading domestic schools or schools in developed countries. They were also required to be academically selective, only enrolling students who met demanding academic performance standards and scored well on an intelligence test. ${ }^{\mathrm{v}}$ 
This is an Accepted Manuscript of an article published by Taylor \& Francis in The Asia Pacific Journal of Anthropology on 8 July 2014, available online:

http://www.tandfonline.com/doi/abs/10.1080/14442213.2014.916341?journalCode=rtap 20

Recognising that many public schools did not meet the above criteria, central, provincial and district governments provided generous routine and additional funding to selected schools - known as SBI Pilots ${ }^{\mathrm{vi}}$ (RSBI) - to help them upgrade to international standard. While the amounts involved varied from region to region and by level of school (i.e. primary, junior secondary, senior secondary), in general they appeared to be much larger than the funding provided to 'regular' schools (Coleman 2009, 3-4).

At the same time, RSBI/SBI were also granted permission to charge fees, in contrast to regular schools which were required to provide basic education for free. ${ }^{\text {vii }}$ The government did not place a cap on these fees, with the result that many RSBI/SBI charged exorbitant rates by local standards: for instance, according to one source, in 2010 tuition fees averaged Rp350,000 (\$US39) per month at RSBI and Rp2 million (\$US223) per month at SBI, with large entrance fees and fees for extracurricular activities being paid in addition (Riady and Prameshwari 2010, A7). By contrast, roughly half of Indonesia's population lives on less than US\$2 per day (World Bank nd). In some cases, RSBIs responded to the flexibility on fees by establishing separate international standard classes for which higher fees were charged than for regular classes, in doing so effectively segregating their students into two groups-those attending cheap regular classes and those attending expensive international classes (Winarti 2008). Some schools distinguished between these students by requiring them to wear separate uniforms.

By 2009, 28, 43, and 18 percent of district-level governments had established at least one $\mathrm{RSBI} / \mathrm{SBI}$ at primary, junior secondary, and senior secondary level respectively, and 60 percent had established at least one RSBI/SBI at senior secondary vocational level (Ministry of Education and Culture 2010, 38-41). The Ministry's Strategic Plan for 20102014 envisaged an increase in these figures to between 70 and 85 percent depending on the level of schooling. 
This is an Accepted Manuscript of an article published by Taylor \& Francis in The Asia Pacific Journal of Anthropology on 8 July 2014, available online:

http://www.tandfonline.com/doi/abs/10.1080/14442213.2014.916341?journalCode=rtap 20

\section{Contesting SBI/RSBIs}

The establishment of RSBI/SBI was consonant not just with the government's objective of improving the quality of education in Indonesia but also the interests and agendas of two key political and social groups: (i) politico-bureaucratic elements within the education bureaucracy and schools and (ii) middle class parents. Under the New Order, Indonesian public schools became part of the New Order's larger 'franchise' structure, the key feature of which was the purchase of government positions in exchange for access to the rents they generated (McLeod 2000). Local community members such as parents, who had previously played a central role in the management of schools, were pushed aside in favour of politico-bureaucrats who bought school positions and used them to make money through corruption and fees (Irawan et al. 2004, 50). The establishment of RSBI/SBI served to enhance rent-seeking opportunities for these individuals by dramatically increasing their schools' revenues via new government grants and higher fees.

At the same time, the establishment of RSBI/SBI also served the interests of middle class parents, especially those of indigenous (pribumi) background, who, following the collapse of the New Order, increasingly demanded access to high quality schools for their children (Sakhiyya 2011, 348). Under the New Order, such parents were unable to send their children to international schools because of a government ban on them enrolling Indonesian citizens. At the same time, they regarded local private schools as an unattractive option because of low quality (in the case of madrasah run by the major Islamic social organisations, Nahdatul Ulama and Muhammadiyah, which were established to service the poor) or their association with the country's minority Chinese and Christian communities (in the case of private Church-run schools) ${ }^{\text {viii }}$ (Hoon 2010; Bjork 2002, 471).

Both the politico-bureaucrats and middle class parents demonstrated support for RSBI/SBI, the former by signing up their schools to the government's RSBI/SBI program 
This is an Accepted Manuscript of an article published by Taylor \& Francis in The Asia Pacific Journal of Anthropology on 8 July 2014, available online:

http://www.tandfonline.com/doi/abs/10.1080/14442213.2014.916341 ?journalCode=rtap 20

and the latter by enrolling their children in them. To the extent that these elements publically defended RSBI/SBIs, they did so with reference to the government's quality agenda and the need to enhance the country's international competitiveness in an era of globalisation, while rejecting the idea that these schools were discriminatory (Ministry of Education and Culture nd; Akuntono 2012).

Aligned against these elements were three main groups: (i) parents of school children excluded from SBI/RSBI (or international standard classes at schools that segregate students into international and regular streams) for financial reasons (hereafter Group 1 parents); (ii) parents who could afford for their children to attend SBI/RSBI (or international standard classes) but were concerned about corrupt school management undermining educational quality (hereafter Group 2 parents); and (iii) teachers at SBI/RSBI who were sympathetic to either or both of these groups of parents. These three groups publically challenged the government's policies on SBI/RSBIs and their implementation on a number of grounds:

- that SBI/RSBI breached Constitutional requirements for free basic education because they charged fees;

- that these schools' fees often disappeared into the pockets of education bureaucrats and school officials rather than contributing to improvements in educational quality and facilities;

- that, for both of the above reasons, SBI/RSBI fees were illegal charges (pungutan liar);

- that SBI/RSBI generally failed to meet requirements to provide scholarships to students from poor backgrounds;

- that schools which segregated students into international and regular classes often used government support for and fees from regular students to subsidise the provision of international standard classes and associated new facilities; and

- that, by effectively excluding students from poor backgrounds from attending SBI/RSBI/international standard classes and favouring the 
This is an Accepted Manuscript of an article published by Taylor \& Francis in The Asia Pacific Journal of Anthropology on 8 July 2014, available online:

http://www.tandfonline.com/doi/abs/10.1080/14442213.2014.916341?journalCode=rtap 20

provision of international standard classes over regular ones, these schools created a two 'caste' education system, thereby worsening inequality (Auditan nd; Winarti 2008; Seputar Indonesia 2007; Metrotvnews.com 2012; Wedhaswary 2012).

Parents formed a series of small-scale, often school-specific and temporary organisations to represent their interests, the most prominent of which have been the Alliance of Parents Concerned About Transparency in Education Funds (Auditan), an informal grouping of parents of children at a variety of Jakarta schools committed to 'promoting and developing management of education funds that is democratic, transparent and accountable and oriented towards the direct benefit of students' (Auditan nd); and the Alliance of Parents Concerned About Indonesian Education (APPI), a successor to Auditan that involves the same key activists (Wedhaswary 2012). To press their case, these organisations have engaged in a range of activities including lobbying of local education officials and local parliamentary members; seeking redress in relation to corruption and excessive fee-charging at specific schools via state institutions such as the police, Attorney-General's office, Anti-Corruption Commission, and National Human Rights Commission; and raising awareness about the problems associated with RSBI/SBI by speaking to the press and other interested groups, even foreign researchers looking into the issue such as ourselves (Rosser and Joshi 2013). ${ }^{\text {ix }}$

Importantly, for our purposes, Auditan/APPI has been helped in its endeavours by NGO activists concerned about human rights issues and/or corruption in state institutions. ${ }^{\mathrm{x}}$ Particularly important in this respect have been activists associated with the Public Services Monitoring Division of Indonesia Corruption Watch (ICW), a leading anticorruption NGO in Jakarta. ICW facilitated the formation of Auditan/APPI, provided it with a physical base at ICW's office, and helped expand its network through the establishment of the Education Coalition, a group of NGOs, teacher unions, and parents' organisations in and around Jakarta that engage in advocacy work on education issues. ${ }^{\mathrm{x}}$ It has also collaborated with Auditan/APPI on efforts to bring the issue of school corruption at RSBI/SBI and other schools to the attention of the Anti-Corruption 
This is an Accepted Manuscript of an article published by Taylor \& Francis in The Asia Pacific Journal of Anthropology on 8 July 2014, available online:

http://www.tandfonline.com/doi/abs/10.1080/14442213.2014.916341?journalCode=rtap 20

Commission, the National Ombudsman, and other state agencies responsible for dealing with this issue (Lestari 2011). Finally, with a high public profile, good access to the media, and an active publishing arm, ICW has been able to help Auditan/APPI raise public awareness by holding joint press conferences, publishing a book on school corruption in 2011 (Wisudo et al. 2011), and holding other public events.

Despite their activism, parents groups and their supporters in the NGO movement had little success in challenging the government's policy on SBI/RSBIs prior to the launching of the Constitutional Court case. According to parents at Auditan/APPI and activists at ICW, officials at local basic education agencies were generally unwilling to take action against school principals and teachers in response to parents' complaints about 'illegal'xii school fees and corrupt school management because they had a vested interest in the preservation of such fees. In cases where they did take action, the penalties for school principals and teachers were fairly light - transfer to another school rather than demotion or dismissal. ${ }^{\text {xii }}$ Parents groups also generally found the police force and the AttorneyGeneral's Office (AGO) unresponsive to their concerns, reflecting the dominance of politico-bureaucratic elements within these institutions. In both cases, there appears to have been an unwillingness to pursue cases unless they generated a financial return for the officials involved. ${ }^{\text {xiv }}$

With ICW's assistance, many parents lodged complaints about 'illegal' school fees with the Corruption Eradication Commission (KPK), an institution that had demonstrated up to that point a strong willingness and ability to prosecute corrupt officials. But the KPK was unable to act as it is restricted to dealing with large-scale corruption cases - that is, ones involving corruption leading to a minimum state loss of Rp 1 billion (around AUD\$ 90,000). The national Ombudsman's office was not much help either: while politicobureaucratic elements were not strong within this institution, it was constrained by limited powers and underfunding. ${ }^{\mathrm{xv}}$ Some parents appealed to local parliaments for assistance but, again, found this ineffective. While local parliamentarians often expressed public support for their cause, helping to generate media attention, they lacked the authority to compel the police, the AGO, or the respective regional education agency to act against 
This is an Accepted Manuscript of an article published by Taylor \& Francis in The Asia Pacific Journal of Anthropology on 8 July 2014, available online:

http://www.tandfonline.com/doi/abs/10.1080/14442213.2014.916341?journalCode=rtap 20

school principals and teachers who charge 'illegal' fees, reflecting their position within the legislative rather than executive arm of government. At best, the increased media attention amplified pressure on local basic education agency officials to take action (Rosser and Joshi 2013).

As such, the Constitutional Court case can be seen as having been born out of frustration on the part of parents and their NGO allies with other available avenues for seeking justice.

\section{The Constitutional Court Case}

In this context, three parents (Andi Akbar Fitriyadi, Milang Tauhida, and Nadya Masykuria) decided to apply to the Constitutional Court for judicial review of Article 50 (3) in Law 20/2003 on a National Education System, the article that provides the legal foundation for the establishment of RSBI/SBI. The Constitutional Court has the authority to review laws and their individual articles to determine whether they accord with the amended 1945 Constitution. ${ }^{\text {xvi }}$ It can rule them legally invalid, effectively removing them from the statute books. Accordingly, the three parents requested that the Constitutional Court determine whether Article 50 (3) —which states that 'national and/or regional governments will establish at least one educational institution at every educational level to become an international standard educational institution'-conforms with the Constitution, in particular its provisions providing citizens with a right to free basic education, providing for a single national education system, and stating that Bahasa Indonesia is the only national language (Mahkamah Konstitusi 2012a). The first hearing of their case was held in January 2012 and subsequent hearings were held between February and May 2012.

The three parents' decision to take their concerns about SBI/RSBIs to the Constitutional Court case reflected a strategic judgment on their part and that of their NGO supporters that this would be more likely to yield a positive result than going to the Supreme Court, 
This is an Accepted Manuscript of an article published by Taylor \& Francis in The Asia Pacific Journal of Anthropology on 8 July 2014, available online:

http://www.tandfonline.com/doi/abs/10.1080/14442213.2014.916341 ?journalCode=rtap 20

the main alternative option. While Article 50 (3) provided the legal foundation for the establishment of SBI/RSBIs, lower-level implementing regulations-specifically, Government Regulation 47/2008 on Education Funding and Minister of Education Regulation 78/2009 on the Implementation of International Standard Schools in Primary and Secondary Education - provided them with permission to charge fees, the aspect of SBI/RSBI policy most vulnerable to challenge on constitutional grounds. ${ }^{\text {xvii }}$

Authority to review lower-level implementing regulations rests with the Supreme Court, an institution that has been widely criticised for corruption and inefficiency. Hence, while the three parents would have had a much stronger legal case at the Supreme Court, they judged that their chances of victory were greater in the Constitutional Court because of its relative professionalism and efficiency. As one leading activist lawyer from an NGO involved in the case put it: 'When we go to the Constitutional Court, we usually win' whereas it take a long time to get a Supreme Court decision and the result is 'uncertain.'xviii

The three parents and their lawyers argued that Article 50 (3) breached the 1945 Constitution for five reasons:

(i) RSBI/SBI conflict with the desire expressed in the Preamble to the 1945 Constitution to develop the intellectual life of the nation (mencerdaskan kehidupan bangsa) given that graduates with international standard/developed country competencies are not necessarily what Indonesia requires;

(ii) $\mathrm{RSBI} / \mathrm{SBI}$ create dualism within Indonesia's national education system that is inconsistent with references in the 1945 Constitution to 'a single national education system';

(iii) $\mathrm{RSBI} / \mathrm{SBI}$ are a form of liberalization of education because the state is abrogating its responsibility to completely fund basic education by allowing them to charge fees; 
This is an Accepted Manuscript of an article published by Taylor \& Francis in The Asia Pacific Journal of Anthropology on 8 July 2014, available online:

http://www.tandfonline.com/doi/abs/10.1080/14442213.2014.916341 ?journalCode=rtap 20

(iv) RSBI/SBI give rise to discrimination and class-based division (kastanisasi) which breaches the rights of poor citizens, especially those who are not academically gifted and therefore unable to access scholarships to SBI/RSBI; and

(v) RSBI/SBI have the potential to destroy the essential character of the Indonesian people, which is defined by the use of Bahasa Indonesia, because they prioritise English as the language of instruction (Mahkamah Konstitusi 2012a).

According to the Laws and regulations governing 'legal standing' at the Constitutional Court, those applying for judicial review of a law or article/s must be able to demonstrate that their Constitutional rights have been breached by the law/article/s under review in order for their case to be considered (Asshiddiqie 2006, 68-69). Hence the three parents further argued that their respective rights had been breached by Article 50 (3) in the following ways:

Andi Akbar Fitriyadi: $\quad$ because he lacked the financial resources required to pay enrolment and other fees at an RSBI in Jakarta.

Milang Tauhida: because her child was discriminated against at an RSBI in Jakarta when the school divided classes in regular and RSBI streams.

Nadya Masykuria: because her children's RSBI schools demanded payment of fees without adequate prior notice and, in the case of the first school, refused to grant a fee reduction when she requested one on financial grounds.

The Court's judgement in their favour in January 2013 ruled that Article 50 (3) of Law 20/2003 was unconstitutional and no longer had legal force. In so doing, it effectively struck out all subordinate regulations related to SBI/RSBI including Minister of Education Regulation 78/2009 and the relevant parts of Government Regulation 47/2008. In the wake of the decision, the government secured the Court's agreement to continue 
This is an Accepted Manuscript of an article published by Taylor \& Francis in The Asia Pacific Journal of Anthropology on 8 July 2014, available online:

http://www.tandfonline.com/doi/abs/10.1080/14442213.2014.916341?journalCode=rtap 20

the SBI/RSBI policy until the end of the 2012-2013 school year. But it has not subsequently revived the policy in different form, despite early indications that it would (Damarjati 2013). It has encouraged parents to make 'voluntary contributions' to exSBI/RSBI and some local governments have chosen to provide these schools with additional funds to maintain their facilities (Suaramerdeka.com 2014). But, formally at least, these schools no longer have the authority to charge fees.

The upshot of the Constitutional Court case has thus been to shift government policy in favour of promoting poor people's access to the country's top public schools without necessarily compromising on quality. All things being equal, the elimination of fees should increase poor people's access to these schools by reducing their cost (although other financial and non-financial barriers to access will remain). The effect on qualityat least to the extent that quality is a function of funding - will depend on whether exSBI/RSBI can successfully replace lost fee income with increased voluntary contributions and government grants. One could argue that, in seeking elimination of SBI/RSBI fees, the three parents have jeopardised government efforts to improve educational quality. But their case was fundamentally about who pays for and has access to quality education rather than whether quality should be improved. In abolishing SBI/RSBI, the Constitutional Court effectively agreed with the parents that public education funding is a public rather than private responsibility except to the extent that parents wish to contribute voluntarily. The implication of its decision with regards to who has access to quality education is less clear, however. The parents' view -implied by their expressed concern about the position of non-academically gifted students-is that quality education should be offered on a universal basis, not just to academically gifted students. But the Court's decision seems to leave resolution of this issue to government.

\section{Legal Mobilisation and the Constitutional Court Case}

There is little doubt that the three parents—Fitriyadi, Tauhida, and Masykuria—played a key role in the case and that their decision to take the SBI/RSBI issue to the Constitutional Court reflects autonomous choice on their part. All three appear motivated by a deep 
This is an Accepted Manuscript of an article published by Taylor \& Francis in The Asia Pacific Journal of Anthropology on 8 July 2014, available online:

http://www.tandfonline.com/doi/abs/10.1080/14442213.2014.916341?journalCode=rtap 20

sense of injustice at the way in which they were treated by SBI/RSBI and a sense that their rights had been infringed. In interview, Fitriyadi made this clear when he stated that 'the situation for poor bright children is not fair (tidak adil)' and 'all citizens have a right to education' (not just the rich). ${ }^{\text {xix }}$ Similarly, Tauhida stated in interview that her involvement in the court case stemmed from the 'intimidatory' and 'discriminatory' treatment her son received at school, emotive terms conveying a clear sense of injustice. ${ }^{\mathrm{xx}}$ In addition, the parents' decision to take matters to the Constitutional Court reflected a strategic judgment on their part that this was the most effective way to seek redress for breaches of their rights, given the ineffectiveness of other parents' earlier efforts to seek justice through other avenues, as discussed above. In interview, Tauhida exhibited an acute understanding of Indonesia's legal system and what could be achieved through different courts, reflecting not only her involvement in the SBI/RSBI case but also a previous court case centred on her husband's 'unfair dismissal'. ${ }^{x i}$

However, it is equally clear that the three parents did not launch and sustain the Constitutional Court case on their own. They acted in concert with activists (especially activist lawyers) from a range of NGOs including ICW, the Institute for Policy Research and Advocacy (ELSAM) (a prominent Jakarta-based human rights NGO), the Public Interest Lawyer Network (PIL-NET) (a group that does pro bono legal work on cases that have a public interest dimension), Schools Without Borders (an NGO that promotes 'alternative education'), and the Education Coalition. They also received support from various other parents, teachers at RSBI/SBI, and academics. For Fitriyadi-and possibly the other parents involved in the case-collaboration with these NGOs was underpinned by a sense that they were on his side and could be trusted. .xii $^{\text {. }}$

The activist lawyers associated with ICW and ELSAM were arguably the most crucial to ensuring that the three parents were able to mobilise the expertise and resources required to mount the case. For instance, the decision to launch the case in the first place appears to have emerged out of discussions between the three parents, other parents, teachers and activists at these organisations rather than at the instigation of the three parents themselves. ${ }^{\text {xiii }}$ The three parents - and other parents who supported them-were not 
This is an Accepted Manuscript of an article published by Taylor \& Francis in The Asia Pacific Journal of Anthropology on 8 July 2014, available online:

http://www.tandfonline.com/doi/abs/10.1080/14442213.2014.916341?journalCode=rtap 20

mere patsies and the fact that they could claim to meet the criteria for legal standing at the Court meant that the case could not go ahead without them. However, it is clear that much of the initiative and drive for the case came from their NGO supporters, in particular, ICW, which, as noted above had by this point engaged in a great deal of activism around the issue. ${ }^{\text {xxiv }}$

Lawyers from these two NGOs prepared the application for judicial review, provided free legal representation for the three parents, and mobilised scholars, parents and teachers within their respective networks to appear as witnesses and experts during the case. Where these experts did not provide services for free, the NGOs covered their costs. ${ }^{\mathrm{xx}} \mathrm{A}$ number of NGO activists also joined the three parents as applicants for the judicial review although the fact that they could not demonstrate that their Constitutional rights had been breached by Article 50 (3) meant that their legal standing at the Constitutional Court was open to potential challenge. Finally, because the two NGOs had both been involved in a number of previous Constitutional Court cases, ${ }^{\mathrm{xxvi}}$ they were able to provide specific know-how about how to operate at the Constitutional Court.

In sum, then, from the beginning to the end, the case illustrates a collective endeavour that involves contributions from a range of actors, not simply an individualistic choice on the part of the three parents. It was built, not only on bold justice-seeking on the part of the three parents, but also the presence of a support structure providing access to organisations with experience at the Constitutional Court (Epp's repeat players), lawyers willing and able to support their case, networks of experts and witnesses, and more generally, the financial and technical resources required to mount and sustain the case. Given that the three justice-seekers are people of modest financial means and with limited networks-something that is clearly indicated by the grounds on which their Constitutional rights were allegedly breached ${ }^{\mathrm{xxvii}}$ - it is unlikely that they would ever have gotten their case to the Constitutional Court without this support just as their NGO supporters would have gotten nowhere without their willingness to participate, given the matter of legal standing and the fact that their involvement provided legitimacy to the cause. 
This is an Accepted Manuscript of an article published by Taylor \& Francis in The Asia Pacific Journal of Anthropology on 8 July 2014, available online:

http://www.tandfonline.com/doi/abs/10.1080/14442213.2014.916341?journalCode=rtap 20

ICW's central involvement in the case, however, meant that the three parents' concerns inevitably became bound up with that NGO's anti-corruption agenda and in a way that sometimes contradicted their interests. For instance, the initial application for judicial review prepared by ICW and ELSAM placed a very strong emphasis on the problems associated with corruption in management at SBI/RSBIs, particularly the fact that corruption undermined efforts to improve educational quality at these schools (ICW and ELSAM 2012). Corruption at SBI/RSBIs is a concern to Group 1 as well as Group 2 parents, given that it accounts for part of the fees that make an education at RSBI/SBI unaffordable for the former (Rosser and Joshi 2013). But a strong focus on corruption arguably weakened the legal argument-something that is important in the context of the Constitutional Court given its relatively high level of professionalism-because the case was fundamentally about the constitutionality of SBI/RSBIs, not the extent to which they have been affected by corruption. It was not an anti-corruption case. While the initial application was subsequently revised and the focus on corruption reduced (Mahkamah Konstitusi 2012a), this tendency to frame the three parents' concerns in anti-corruption terms continued throughout the court proceedings, constraining the extent to which the case focused on the injustices experienced by the parents.

ICW's central involvement in the case also served to benefit some Group 2 parents over others. While Group 2 parents have been united in their opposition to corruption at SBI/RSBI, they have been divided into two camps: more elitist elements have wanted to preserve the privileges associated with schooling their children at SBI/RSBIs (e.g. increased access to funding, higher status, exclusiveness, better quality education) and hence have not wanted to see them abolished while more progressive Group 2 parents concerned about social justice have been prepared to see these schools abolished. ICW's primary concern in campaigning around the issue of SBI/RSBI has been to promote its anti-corruption agenda but it has also had a strong social justice orientation, something that is reflected for instance in its critique of neo-liberalism's influence on Indonesian education policy and in particular growing 'privatisation' of education services (see Irawan et al. 2004). The effect has been to give it a predisposition towards the interests 
This is an Accepted Manuscript of an article published by Taylor \& Francis in The Asia Pacific Journal of Anthropology on 8 July 2014, available online:

http://www.tandfonline.com/doi/abs/10.1080/14442213.2014.916341?journalCode=rtap 20

of Group 1 and progressive Group 2 parents over those of more elitist Group 2 parents. By supporting the Constitutional Court case, rather than say pursuing the issue through anti-corruption channels, ICW effectively backed the former over the latter. ${ }^{\text {xxviii }}$

\section{Conclusion}

The SBI/RSBI Constitutional Court case illustrates clearly the important role of SSLMs in facilitating efforts by Indonesian justice-seekers to seek redress for perceived injustices. The three parents' ability to launch and sustain this case reflected not only their own boldness and strategic choices but also the fact that, via cooperation with NGOs and other actors, they gained access to the financial and technical resources required to take their concerns to court. Without this support, they probably would not have been able to mount their case in the first place. At the same time, the case also illustrates the potential problems for justice-seekers that emerge from contradictions between the political agendas of supporting organisations and justice-seekers themselves. Where private actors constitute the principal form of support for justice-seekers, there is potential for the latter's aspirations and interests to be sacrificed to suit the former's agenda.

On this second point, there are some parallels here with Epp's (1998, 71-110) analysis of India. Epp argues that India failed to achieve a 'rights revolution' because the SSLM was dominated by private actors whose interest in rights causes proved ephemeral: when the political threat that generated their support for legal mobilization around rights issues evaporated, so too did their financial and other support for such mobilisation. The SBI/RSBI case indicates that a support structure for legal mobilization dominated by private actors - while it may ultimately prove effective in certain respects - can also skew the nature of legal cases in a way that potentially undermines justice-seekers' causes by giving them particular orientations and privileging particular interests.

Through the lens of legal mobilization we have thus offered a different perspective through which to analyse the collective experience of those who seek redress through 
This is an Accepted Manuscript of an article published by Taylor \& Francis in The Asia Pacific Journal of Anthropology on 8 July 2014, available online:

http://www.tandfonline.com/doi/abs/10.1080/14442213.2014.916341?journalCode=rtap 20

Indonesian courts. This has involved a shift conceptually away from a focus on the role of judges, court design and the attitudes and choices of individual justice-seekers to the actors 'in the middle' who mediate the relationship between these elements. In essence, we have suggested that the strength of demand for justice - in particular, whether it can be translated from individual preferences into effective legal action-varies according to the presence and characteristics of the support structure. In this article we have sought to tease out how individuals operate with and through multiple organisations and institutions to seek justice. The case of a small group of parents taking their case against SBIs to the Constitutional Court provides compelling evidence of the key role of support structures in shaping citizens ability to make effective legal challenges.

In policy terms, one could conclude from this analysis that Indonesia should develop a legal aid system in which government departments or agencies (rather than NGOs) become the key providers of legal aid. However, going down this path is not straightforward, on the one hand, because it is costly and governments face serious budget constraints and, on the other hand, because citizens' trust in government institutions in Indonesia is very low reflecting the dominance of predatory elements within these institutions. Shifting towards greater government provision of legal aid would not necessarily reduce the problems associated with political disjunctures between the interests of justice-seekers and those of actors within the support structure-indeed, to the extent that government legal aid institutions became captured by predatory interests, it would probably make them worse.

Perhaps in recognition of these problems, the Indonesian government has recently created a new regulatory structure for legal aid - the key element of which is Law 16/2011 on Legal Aid - that is likely to see NGOs remain the principal providers of legal aid. In the wake of this Law, the government has accredited 310 organisations from across the country to provide legal aid and receive limited government funding. While a small number of these organisations are linked to courts or government departments, the vast majority appear to be charitable foundations, legal aid institutes connected to universities, or some other form of NGO (although the provenance of many organisations is unclear) 
This is an Accepted Manuscript of an article published by Taylor \& Francis in The Asia Pacific Journal of Anthropology on 8 July 2014, available online:

http://www.tandfonline.com/doi/abs/10.1080/14442213.2014.916341?journalCode=rtap 20

(Syamsudin 2013). ${ }^{\text {xix }}$ In the foreseeable future, therefore, the key challenge will be to ensure that these NGOs are effective supporters of the poor and marginalised citizens that they represent. This case has shown that some such organisations have played a crucial role in helping ordinary citizens to pursue their rights through the court system: the focus has to be on helping them to do this job better in the future.

\section{References}

Akuntono, I. 2012. "Saksi Ahli: RSBI Tidak Diskriminatif." Kompas.com, 2 May, accessed 28 June 2012. http://megapolitan.kompas.com/read/2012/05/02/13334232/Saksi.Ahli.RSBI.Tidak.Dis kriminatif.

Asshiddiqie, J. 2006. Hukum Acara: Pengujian Undang-undang. Jakarta: Konstitusi Press.

Auditan nd. Mengenal Perkumpulan Auditan. accessed 14 January 2010. www.antikorupsi.org/docs/profilauditan.pdf.

Bedner, A. and J. Vel 2010. "An Analytical Framework for Empirical Research on Access to Justice." Law, Social Justice and Global Development Journal 1. http://www.go.warwick.ac.uk/elj/lgd/20010_1/bedner_vel

Berenschot, W., A. Bedner, E. Laggut-Terre, and D. Novrianti 2011. Akses Terhadap Keadilan: Perjuangan Masyarakat Miskin dan Kurang Beruntung Untuk Menuntut Hak di Indonesia. Jakarta: KITLV Jakarta.

Bjork, C. 2002. "Reconstructing Rituals: Expressions of Autonomy and Resistance in a Sino Indonesian School.” Anthropology and Education Quarterly 33 (4): 465-491.

Butt, S. 2006. “Zealous Reformers.” Inside Indonesia, 87. 
This is an Accepted Manuscript of an article published by Taylor \& Francis in The Asia Pacific Journal of Anthropology on 8 July 2014, available online:

http://www.tandfonline.com/doi/abs/10.1080/14442213.2014.916341 ?journalCode=rtap 20

Butt, S. and T. Lindsey 2012. The Constitution of Indonesia: A Contextual Analysis, Oxford: Hart Publishing.

Coleman, H. 2009. “Indonesia's 'International Standard Schools': What Are They For?” paper presented at the $8^{\text {th }}$ Language and Development Conference, Dhaka, 23-25 June, accessed July 2012. http://leeds.academia.edu/HywelColeman/Papers/721002/Indonesias_International_Stan dard_Schools_What_are they_for,

Cowan, J. 2006. "Culture and Rights After Culture and Rights." American Anthropologist 108 (1): 9-24.

Crouch, M. 2008. "Indonesia's National and local Ombudsman Reforms: Salvaging a Failed Experiment?" In Indonesia: Law and Society, edited by Tim Lindsey, 382-405. Sydney: the Federation Press.

Damarjati, D. 2013. "Mendikbud Belum Putuskan Status Sekolah Kategori Mandiri Pasca RSBI.” $\quad 19 \quad$ accessed 2013. http://news.detik.com/read/2013/01/13/131732/2140683/10/mendikbud-belumputuskan-status-sekolah-kategori-mandiri-pasca-rsbi

Epp, C. 1998. The Rights Revolution: Lawyers, Activists, and Supreme Courts in Comparative Perspective. Chicago: University of Chicago Press.

Hoon, C. 2011. "Mapping 'Chinese' Christian Schools in Indonesia: Ethnicity, Class and Religion.” Asia Pacific Education Review 12 (3): 403-411.

Hukumonline.com. 2013. "Dana Bantuan Hukum Bisa Dipakai Untuk Gugat Pemerintah”, $\quad$ accessed $\quad 30 \quad$ March 2014. http://www.hukumonline.com/berita/baca/lt512c88d7e426c/dana-bankum-bisa-dipakaiuntuk-gugat-pemerintah. 
This is an Accepted Manuscript of an article published by Taylor \& Francis in The Asia Pacific Journal of Anthropology on 8 July 2014, available online:

http://www.tandfonline.com/doi/abs/10.1080/14442213.2014.916341? journalCode=rtap 20

Irawan, A., Eriyanto, L. Djani, L., and A. Sunaryanto 2004. Mendagangkan Sekolah. Jakarta: Indonesia Corruption Watch.

Lestari, R. 2011. “Korupsi Pun Masuk Sekolah,” Okezone.com, accessed 29 June 2012. http://kampus.okezone.com/read/2011/07/11/373/478428/korupsi-pun-masuk-sekolah

Lev, D. 1987. Legal Aid in Indonesia, Centre of Southeast Asian Studies Working Paper No. 44, Monash University, Clayton.

Lev, D. 1998. "Lawyers' Causes in Indonesia and Malaysia." In Cause Lawyering: Political Commitments and Professional Responsibilities, edited by A. Sarat and S. Scheingold, 431-452. Oxford: Oxford University Press.

Mahkamah Konstitusi 2012a. Ringkasan Perbaikan Permohonan Perkara, Registrasi Nomor: 5/PUU-X/2012, Tentang "Pelaksanaan Program Rintisan Sekolah Bertaraf Internasional (RSBI) dan Sekolah Bertaraf Internasional Dapat Mengesampngkan Sistem Pendidikan Nasional”.

McLeod, R. 2000. "Soeharto’s Indonesia: A Better Class of Corruption.” Agenda 7 (2): 99-112.

Merry, S. 2006. "Transnational Human Rights and Local Activism: Mapping the Middle." American Anthropologist 108 (1): 38-51.

Metrotvnews.com (2012) "RSBI Cekik Leher Kelas Menengah ke Bawah.” accessed 27 June 2012. http://www.metrotvnews.com/read/news/2012/04/07/87707/RSBI-Cekik$\underline{\text { Leher-Kelas-Menengah-ke-Bawah/6 }}$ 
This is an Accepted Manuscript of an article published by Taylor \& Francis in The Asia Pacific Journal of Anthropology on 8 July 2014, available online:

http://www.tandfonline.com/doi/abs/10.1080/14442213.2014.916341?journalCode=rtap 20

Mietzner, M. 2010. "Political Conflict Resolution and Democratic Consolidation in Indonesia: The Role of the Constitutional Court." Journal of East Asian Studies 10: 397424.

Ministry of Education and Culture (nd) "Pengantar Rintisan Sekolah Bertaraf $\begin{array}{llll}\text { Internasional,' } & \text { accessed } & 28 & \text { June }\end{array}$ http://dikdas.kemdikbud.go.id/content/rsbi/pengantar/pengantar-ri.html

Ministry of Education and Culture 2010. Rencana Strategis (Renstra) Kementerian Pendidikan Nasional Tahun 2010 - 2014. Jakarta: Ministry of Education and Culture.

Ministry of National Education (2005) Strategic Plan: 2005-2009. Jakarta: Ministry of National Education.

Patnistik, E. 2009. "Sekolah Lakukan Pungli, Orang Tua Murid Mengadu ke DPRD." $\begin{array}{lllll}\text { Kompas.com, } & \text { accessed } & 27 & \text { July }\end{array}$ http://tekno.kompas.com/read/2009/05/26/18380174/sekolah.lakukan.pungli.orangtua.m urid.mengadu.ke.dprd

Riady, S. and P. Prameshwari 2010. "Are State International Schools Pricing Students Out?" Jakarta Globe, 15 June. A7.

Rosser, A. and A. Joshi 2013. "From User Fee to Fee Free: The Politics of Realising Universal Free Basic Education in Indonesia.” Journal of Development Studies 49 (2): 175-189.

Sakhiyya, Z. 2011. "Interrogating Identity: The International Standard School in Indonesia." Pedagogy, Culture and Society 19 (3): 345-365.

Seputar Indonesia (2007) "Pungli Marak di Sekolah Unggulan.” Seputar Indonesia, 27 Mei, accessed 27 June 2012.http://m.antikorupsi.org/?q=node/10399 
This is an Accepted Manuscript of an article published by Taylor \& Francis in The Asia Pacific Journal of Anthropology on 8 July 2014, available online:

http://www.tandfonline.com/doi/abs/10.1080/14442213.2014.916341? journalCode=rtap 20

Suaramerdeka.com. 2014. "Pemkab Karanganyar Tetap Beri Perhatian Sekolah Eks RSBI”. $\quad 1 \quad$ March, $\quad$ accessed 29 March 2014. http://www.suaramerdeka.com/v2/index.php/read/news/2014/03/01/192879/Pemkab$\underline{\text { Karanganyar-Tetap-Beri-Perhatian-Sekolah-Eks-RSBI }}$

Syamsudin, A. 2013. "Pengumuman Hasil Verifikasi/Akreditasi Pelaksanaan Pemberian Bantuan Hukum Berdasarkan Undang-Undang Nomor 16 Tahun 2011 Tentang Bantuan Hukum".

Van de Meene, I. and B. van Rooij 2008. Access to Justice and Legal Empowerment: Making the Poor Central in Legal Development Cooperation. Leiden: Leiden University Press.

Wedhaswary, I. 2012. “Kemdikbud Harus Evaluasi RSBI.” Kompas.com, 4 January, accessed 27 June 2012.

http://tekno.kompas.com/read/2012/01/04/13395796/Kemdikbud.Harus.Evaluasi.RSBI

Winarti, A. 2008. "State Schools Found Favoring Wealthier Students.” The Jakarta Post, 27 June, 5.

Wisudo, B., A. Irawan, H. Fadjar, and Friends 2011. Sekolah Harapan: Sekolah Bebas Korupsi. Jakarta: Indonesia Corruption Watch.

World Bank (nd) "Poverty Headcount Ratio at \$2 a Day (PPP) (\% of Population)." accessed July 2012. http://data.worldbank.org/indicator/SI.POV.2DAY. 
This is an Accepted Manuscript of an article published by Taylor \& Francis in The Asia Pacific Journal of Anthropology on 8 July 2014, available online: http://www.tandfonline.com/doi/abs/10.1080/14442213.2014.916341?journalCode=rtap 20

\section{Endnotes}

ii The government has indicated a desire to maintain the SBI/RSBI policy in a revised form. See Damarjati (2013).

iii During the New Order, only foreigners were permitted to attend international schools. While regulatory changes since the fall of the New Order mean that Indonesian nationals can now attend international schools up to a certain percentage, they have refused to open their doors widely and consequently still predominantly service the expatriate community (Sakhiyya 2011, 348).

iv See Minister of Education Regulation 78/2009 on the Implementation of International Standard Schools in Primary and Secondary Education, Article 1(8).

${ }^{\vee}$ See Minister of Education Regulation 78/2009, especially Articles 4, 5, 6, 10, 16 and 20.

vi The Indonesian is Rintisan Sekolah Bertaraf Internasional.

vii These differences are specified in Government Regulation 48 on Education Funding, Article 9. Minister of Education Regulation 78/2009, Article 13 (3), reaffirms the permission granted to SBI to charge fees.

viii Pribumi Indonesians are predominantly Moslem while Chinese Indonesians are predominantly Christian.

ix This research has benefited enormously from the help of individuals associated with Auditan/APPI, in particular Jumono and Handaru Widjatmiko.

x One of Auditan's 2007 Press Releases lists a number of NGOs as being within its 'network' including Indonesian Corruption Watch (ICW); Voice of Concerned Mothers (SIP), the Indonesian Forum for Budget Transparency (FITRA); and the Indonesian Consumers Association (YLKI) (Auditan 2007).

${ }^{x i}$ Interview with Ade Irawan, former Manager of ICW's Public Services Monitoring Division and Secretary of the Education Coalition, Jakarta, October 2009.

xii We have put the word illegal in inverted commas here and elsewhere in recognition of the fact that while SBI/RSBI fees were ultimately deemed unconstitutional, they were permitted under various government regulations.

xiii Interviews with Isnetty Saibi, a former teacher at SDN RSBI Rawamangun 12 Pagi and Handaru Widjatmiko, Jakarta, October 2009.

xiv Interviews with Jumono and Ade Irawan, June and October 2009.

${ }^{x v}$ As best we can tell, parents groups and their NGO supporters never lodged a complaint with the Ombudsman. See Crouch (2008) on the Ombudsman's powers..

xvi Originally formulated and introduced as Indonesian nationalist forces prepared for armed struggle against the Dutch in 1945, the 1945 Constitution was revised after the fall of the Suharto's New Order. The revised version is often referred to as the 'amended' 1945 Constitution. See Butt and Lindsey (2012) on the Indonesian Constitution.

xvii Permission for SBI/RSBI to charge fees would appear, on the face of it, to breach the 1945 Constitution's requirement that government fund the cost of basic education.

xviii Interview with Zainal Abidin, ELSAM, Jakarta, January 2012.

xix Interview, Jakarta, 1 March 2013.

xx Interview, Jakarta, 7 March 2013.

xxi She claims to have successfully 'defended' her husband in this case despite having no formal legal training by reading up on Indonesian law and legal procedure.

xxii Interview, Jakarta, 1 March 2013.

xxiii Andi Muttaqien, ELSAM, personal communication, July 2012.

${ }^{x x i v}$ Indeed, Fitriyadi only became involved in the court case following an approach by Jumono, parentactivist associated with ICW. Interview with Fitriyadi, Jakarta, 1 March 2013.

xxv Andi Muttaqien, ELSAM, personal communication, July 2012.

${ }^{x x v i}$ For instance, activists from both organisations were involved in the successful challenge to Law 9/2009 on Education Legal Entities (Badan Hukum Pendidikan) in 2009.

xxvii The modesty of Fitriyadi's and Tauhida's financial means also became apparent during interviews. Fitriyadi works as a food seller and lives in a small, crowded and simple house in a Tebet kampung. Tauhida has a more affluent background but appears to have become financially dependent on her parents since her husband lost his job in 2000 .

xxviii In this respect, it is worth noting that the Indonesian Poor People's League (SRMI), another Indonesian NGO that has been active in relation to education rights issues but with a more explicitly radical orientation, 
This is an Accepted Manuscript of an article published by Taylor \& Francis in The Asia Pacific Journal of Anthropology on 8 July 2014, available online:

http://www.tandfonline.com/doi/abs/10.1080/14442213.2014.916341 ?journalCode=rtap 20

has not engaged at all with the issue of corruption at RSBI/SBI, presumably seeing this as a middle class cause antithetical to the interests of the poor.

xxix Wicipto Setiadi, the head of the National Legal Development Agency (BPHN), has indicated that government legal aid funding can be used to support challenges to government policy through judicial reviews among other legal mechanisms. See Hukumonline.com (2013). 


\section{University Library}

\section{- M M N E R VA A gateway to Melbourne's research publications}

Minerva Access is the Institutional Repository of The University of Melbourne

Author/s:

Rosser, A;Curnow, J

Title:

Legal Mobilisation and Justice: Insights from the Constitutional Court Case on International Standard Schools in Indonesia

Date:

2014-08-01

Citation:

Rosser, A. \& Curnow, J. (2014). Legal Mobilisation and Justice: Insights from the Constitutional Court Case on International Standard Schools in Indonesia. ASIA PACIFIC JOURNAL OF ANTHROPOLOGY, 15 (4), pp.302-318. https:// doi.org/10.1080/14442213.2014.916341.

Persistent Link:

http://hdl.handle.net/11343/127219 